Island Studies Journal, Vol. 4, No. 2, 2009, pp. 183-202

\title{
At the Intersection of Resident, Research and Recreation Stakeholder Interests: East Maui, Hawai'i, as a Sustainable Tourism Destination
}

John Cusick

University of Hawai ' $i$ at Manoa

Oahu, Hawai 'i, USA

jcusick@,hawaii.edu

\begin{abstract}
The experiences of contemporary protected areas indicate adaptations to challenges brought about by resource management strategies. Resident communities, protected area management, and the tourism industry stakeholders demonstrate that evolving relationships are complex webs of competing and cooperating interests. The geographic isolation of East Maui delayed the cultural disruption of traditional practices and is an area where residents simultaneously resist assimilation and re-create cultural landscapes to offer visitors a glimpse into the past and a view of an emerging future associated with the renaissance of Native Hawaiian identity. Partnerships have brought about and nurtured the perpetuation of culture and the conservation of biodiversity as stakeholders recognize shared benefits. Among the outcomes are that residents have reconstituted the identity of East Maui as a Hawaiian place with benefits to various stakeholders, including a network of protected areas. A sustainability framework suggests a reappraisal of how to nurture, not alter, East Maui's identity.
\end{abstract}

Keywords: community based tourism, cultural kipuka, golf course development, Hana, Hawai'i, islandness, Maui, protected areas, stakeholders, sustainability framework

(C) 2009 - Institute of Island Studies, University of Prince Edward Island, Canada.

\section{Introduction}

The combination of biological diversity and cultural heritage is routinely cited as being conducive to the development of ecotourism activities (Honey, 1999; Stronza \& Durham, 2008). An increase and expansion of tourism development associated with protected areas facilitate the convergence of stakeholder interests and raise issues related to resident place, research field site, and tourist destination (Howe et al., 1997; Terborgh et al., 2002).

The US State of Hawai'i has an international reputation as a mature tropical mass tourist destination based on an image of "sun and surf" (Sheldon et al., 2005), perhaps best represented by Waikiki's concentration of high-rise hotels along a strip of beach. An abundance of marine, terrestrial and cultural resources in the islands, however, provide for the diversification of tourist experiences. This paper explores the intersection of resident, research and recreation stakeholder interests to consider the implications of ecotourism for rural Hawai' $i$, and in particular, Kipahulu District, Haleakala National Park on the island of Maui (Map 1). 


\section{J. Cusick}

The roles of protected areas are multiple and subject to debate and dispute within different local and national settings, and the protected area literature documents conflict among and between stakeholder groups (Lockwood et al., 2006). The experiences of contemporary protected areas suggest that their roles are not static and that accommodations have been and will likely continue to be made to adapt to challenges brought about by human resource use and/or global climate change. Resident communities, protected area management, and the tourism industry stakeholders demonstrate that evolving relationships are complex webs of competing and cooperating interests. The effective conservation of environmental diversity involves more than the identification and monitoring of such diversity in situ. Concentrations of globally significant biological and cultural diversity, bounded as they are in protected areas or located adjacent to them, are landscapes occupied by resident communities, field research sites, and tourist destinations generally considered too valuable to be left unprotected. These protected natural and cultural landscapes provide the basis for the development of viable ecotourism destinations.

Map 1: Recreation and Resort Development, Island of Maui, Hawai'i (National Park Service, 1989). Inset: Maui County

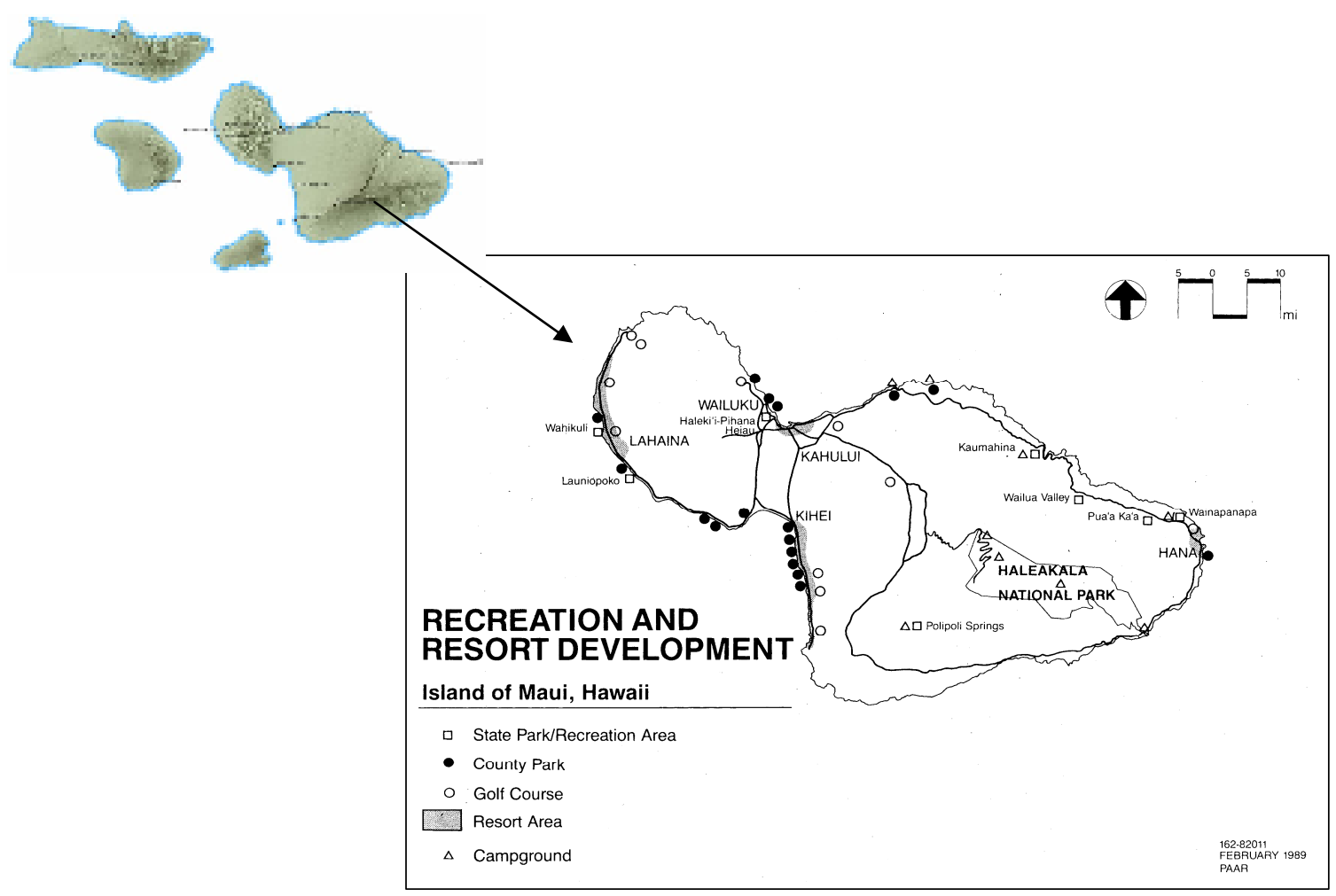


A primary objective of ecotourism is to provide a means of support for both environmental conservation and economic development for resident communities in and adjacent to destinations (Honey, 1999). The initial excitement over this strategy of sustainable development has been tempered by a number of case studies indicating mixed results (Kruger, 2004; Stronza \& Durham, 2008). Although ecotourism research has generally focused on places outside the United States, the concerns are of no less importance to the State of Hawai'i as a result of the islands' economic dependence on the tourism sector (Hawai`i Tourism Authority, 2004).

A sustainability framework addresses issues associated with the environment, economy, culture, and social equity. Our Common Future (World Commission on Environment and Development, 1987) defines sustainable development as the promotion of decision-making and actions whereby the needs of people today are met without compromising the ability of people in the future to meet their own needs. While international organizations and national and local governments continue to provide capacity building workshops for ecotourism advocacy and training, the terms "sustainable development" and "sustainability" are frequently used as justification for such promotional efforts. Communities in and adjacent to tourist destinations, both rural and urban, use participatory problem-solving and conflict-resolution approaches for reaching agreement on how to balance conservation and development. The trends associated with the mobility of human and financial resources associated with globalization have created complex relationships between tourist destinations and sources of the traveling public, often resulting in the degradation of biological and cultural diversity. The decline in diversity has increased the desire to protect the environment, preserve cultural values, and provide social equity such that ecotourism is seen as a viable option. However, for ecotourism planning to actually achieve the goals of habitat conservation, respect for host culture and jobs paying living wages is a complex task.

A conceptual understanding and agreement on defining ecotourism independent of mainstream tourism has become an important component of specialty tourism, sustainable community economic development, and environmental conservation studies (Bulbeck, 2005; McCool \& Moisey, 2001; Wearing \& Neil, 2001). In this context, ecotourism has established a niche and there exists a growing international literature that explores such issues as supply and demand, tourism development and facilities management (Carr \& Higham, 2001; Eagles et al., 2001; Fennell, 2001; Weaver \& Lawton, 2007; Whitlock et al., 1991). Over the last two decades, some of the ecotourism literature has focused on the development of standards (Blamey, 1997; Bjork, 2000; Diamantis, 2004; Fennel \& Eagles, 1990; Higham \& Carr, 2003; Page \& Dowling, 2002; Weaver, 2001), while the inherent ambiguity in the nexus of conservation and development of the early ecotourism literature focused on providing a conceptual understanding of the term and how it was being applied in practice (Boo, 1990; Whelan, 1991; Lindberg \& Hawkins, 1993).

There have been many challenges in determining a more universal conceptual framework for ecotourism, particularly regarding resource management issues in the context of developing economies (Knight \& Gutzwiller, 1995; Stevens, 1997; Weaver, 1998; Honey, 1999; Font \& Tribe, 2000; Godde et al., 2000; Terborg et al., 2002). Ecotourism has been 


\section{J. Cusick}

portrayed as an alternative to mass tourism with minimal, if any, associated negative impacts to the natural environment or host communities. The literature discusses both the benefits (positive impacts) and the costs (negative impacts) of tourism, particularly in the context of sustainable development (France, 1997).

Environmental impacts are a frequent theme and significant positive outcomes are suggested as possible, if ecotourism is conducted according to best practices as identified by trade associations (Buckley, 2004; Haysmith, 1995; Larsen, \& Wearing, 1994; Wearing $\&$ Neil, 1999). Although there is no consensus on the compatibility of tourism and sustainability, there is general agreement in the literature that, if principles are properly adhered to, ecotourism has the potential to minimize negative impacts and enhance positive impacts. This is particularly evident in the early stages of tourism development and prior to communities becoming marketed as mass tourism destinations (Beeton, 1998; Drumm \& Wesche, 1999; Harvey \& Hoare, 1995; Horwich et al., 1993; Scheyvens, 1999).

The scope of ecotourism research at sites of natural and cultural heritage has increased dramatically, partly as a result of increased interest among international organizations to see ecotourism principles minimize the negative consequences of the tourist industry in places considered of "most outstanding value" by the United Nations and affiliated organizations such as the World Heritage Centre and the International Union for the Conservation of Nature (IUCN) (Lockwood, 2006). In addition to minimization of tourism's negative impacts on cultural traditions and socioeconomic conditions, there is gathering interest in the potential for ecotourism to enhance community development (Harvey \& Hoare, 1995; Horwich et al., 1993; Scheyvens, 1999), mitigate traditional user access rights, and improve dialogue with external stakeholders toward developing more responsible forms of tourism activities (Brause, 1992; Hinch, 1998; Zeppel, 2007).

A review of existing ecotourism studies in the State of Hawai' $i$ verified the relative paucity of case studies in comparison to other notable tourist destinations in the Pacific such as New Zealand and the Galapagos, let alone in places that were early adopters of ecotourism strategies such as Nepal, Costa Rica and Kenya. This lack of case studies in an island archipelago highly dependent on the tourism sector justifies the present study as a means to contribute to better understanding what role, if any, ecotourism has in the Hawaiian Islands. Further efforts are required in order to effectively assess what types of ecotourism activities are being promoted, by whom and for whom, and particularly where these activities take place and how they impact natural and cultural resources.

The expanded promotion and increasing popularity of ecotourism activities fuels the desire in many destinations for sustainable tourism development that allows stakeholders to determine the scope of allowable impacts. In the case of the State of Hawai'i, research published in the 1990s concluded that alternatives to mass tourism destinations would contribute to the dispersal of tourists outside of resort enclaves and, as a result, enhance economic opportunities in rural communities dealing with the almost simultaneous collapse of the sugar industry on the islands of Hawai' $i$, Oahu, and later on Kaua' $i$ and Maui (DBEDT, 1994; 1995; Minerbi, 1991; 1994; Rohter, 1994; Mak, 2008). The Hawai' $i$ Department of Business, Economic Development, and Tourism (DBEDT) acknowledged 
the importance of niche tourism, including ecotourism (DBEDT, 2006), and the literature presents both the opportunities and challenges posed by niche tourism, as well as issues related to sustainability (Liu, 1994; Sheldon et al., 2005; DBEDT, 2006; Mak, 2008; Cusick et al., in press).

The challenges for governments, the tourism industry and communities are whether stakeholders can effectively balance environmental conservation and human use. The scale of tourism in the State of Hawai'i strains federal, state, and county resources and the tolerance of local residents who 'host' over half a million visitors in their communities every month of the year, every year. Also, many self-identified ecotours, not often community-based operations, are growing without adequate training, planning, monitoring, certification, or regulation to ensure a commitment to, let alone knowledge of, protecting resources. It is often stated in public forums that communities in the State have an inherent interest in environmental protection and cultural preservation since these efforts protect the quality of life for residents and are critical for sustained economic development. This combination of biological diversity and cultural heritage creates conditions conducive to the development of ecotourism activities that can sustain and enhance those assets.

In 2007, the State of Hawai'i Legislature launched an initiative to achieve sustainability by 2050 (Hawai'i 2050 Sustainability Task Force, 2008), and resurrected interest in ecotourism as a more sustainable alternative to mass tourism. However, as in past challenging economic times, the unprecedented precipitous decline in visitor arrivals beginning in January 2008 and continuing every month of 2009 with projections of no significant change well into 2010 has redirected limited state marketing funds to maintain the mass tourism market share, despite evidence that niche tourism can contribute to both economic sustainability and environmental conservation (Stronza \& Durham, 2008).

The expanding literature that links ecotourism and sustainable development provide a considerable number of case studies that address the specific experiences of local places. More recently, tourism research has explored issues associated with global environmental issues, including climate change (Gössling \& Hall, 2006; Peeters, 2007). As an island state, Hawai' $i$ is a captive to tourism development pressures often controlled by off-island interests on one hand, and on the other by dependency of the importation of basic necessities such as food and fuel. It is increasingly evident that the status quo is no longer sustainable and the state as a whole and island communities themselves are exploring strategies to adapt to new realities. This paper explores a community-driven project in East Maui that perpetuates the identity of an indigenous place still dependent on tourism while attempting to achieve greater autonomy over development decisions.

\section{Resident Place}

Rural communities throughout the Hawaiian Islands are cultural kipuka from which native Hawaiian culture is regenerated and revitalized (McGregor, 1995). Kipuka are the oases of biological diversity that remain after the eruptive forces of Hawai'i's volcanoes destroy 


\section{J. Cusick}

forests and extend coastlines. From the seed bank of flora and fauna that survive in these kipuka, ecological succession regenerates life on new lava flows.

Writing of Waipi'o Valley on the island of Hawai'i, McGregor (1995: 198) suggests "an examination of life in Hawaiian cultural kipuka reveals the strongest and most resilient aspects of the Hawaiian culture and way of life." Included among those locations that survive amidst the "onslaught of post-statehood (1959) development" is East Maui, a widely recognized cultural kipuka and centre of biological diversity.

Haleakala $(3055 \mathrm{~m})$ topographically separates East Maui from central and west Maui and the dormant volcano creates an ecological zonation from sea level coastal habitats, wet and dry forests, to sub-alpine ecosystems. In contrast, central Maui references the low coastal plain that separates Haleakala and the West Maui Mountains. The west side of Maui is mostly in a leeward orientation resulting in an ecological zonation; while providing critical habitat for threatened and endangered species of plants and animals, it is not as diverse due to scale and elevational differences to the slopes of Haleakala.

The forested valleys provide critical habitat for native and endemic biota and communities along the island's windward East Maui coast were sites of early settlement and have allowed the continuation of cultural practices into the contemporary period. Despite the pre-European population's concentration and political development centred in Hana District, archaeological research in East Maui has been limited. Researchers do agree that the subdistricts of Kipahulu and its neighbours, Hana to the northeast and Kaupo to the southwest, were important relative to other districts in the islands because of abundant environmental and human resources (Krauss, 1980; Lueras, 1983; Kirch, 1985; Smith et al., 1985; National Park Service, 1989; Kornbacher, 1993):

"They were coveted lands, prized by the ali' $i$ [nobility (sic)] for their abundance of foodstuffs and all the valued products of the land and sea. Plentiful food and resources made possible a large population, and many followers meant power to the chief controlling the land. Small wonder, then, that Hana and Kipahulu were often the cause of contention among ambitious chiefs. A few miles south, across the Alenuihaha Channel lay Hawai'i, also endowed with wealth and powerful chiefs. As might be expected, warfare was not infrequent" (Soehren, 1963; cited in Kornbacher, 1993).

A preliminary archaeological survey of 85 ha in Kipahulu District, Haleakala National Park $^{1}$ recorded 26 sites and 759 features (primarily stone mounds, walls, and earthen terraces). Present evidence for the prehistoric human population of Kipahulu comes from the physical remains of heiau (temples), house foundations, fortresses, trails, and terraces along the coast and upland slopes of East Maui and inside Haleakala Crater. The moku (district) of Kipahulu was described in 1940 as a landscape that was:

\footnotetext{
${ }^{1}$ Kipahulu District, as used by the National Park Service, refers only to those portions of Kipahulu Valley managed as a protected area, and not to traditional land districts.
} 
“... rich and diverse but (with) scattered agricultural resources. Its great valley and lower fringing forests nourished forest taro and other native food plants, as did the lower kula lands above the sea, where the native homes are today. Formerly sugar plantation, this land is now a cattle ranch" (Sperling, 1998: 156).

Current population density and median household incomes of East Maui are less and the percentage of Native Hawaiian residents higher than central and west Maui.

As a past centre of population and cultural development, East Maui cultural landscapes in the traditional districts of Koolau, Hana, Kipahulu, Kaupo and Kahikinui that currently constitute the Hana District of the County of Maui contribute to the interpretation of precontact Hawai'i. Important cultural sites include the state's largest heiau, extensive trail networks, petroglyphs, and evidence of settlements, some of which are included on or are candidates for the National Register of Historic Places (Sterling, 1998). Additional natural and cultural resource sites are within the boundaries of various protected area status, including State Forest Reserve, State Park, and National Tropical Botanical Garden. Such status provides development options for the communities that are "often singled out (as) a rustic region with numerous Native Hawaiian sites, needing continued protection and oversight" (Blackford, 2001: 96).

\section{Research Field Site}

The slopes of Haleakala $(3,055 \mathrm{~m})$ support four ecological zones found only there and on Mauna Kea (4,205 m) and Mauna Loa (4,170 m) on the (big) island of Hawai' ${ }^{i}$ : the highest mountains in the Hawaiian Islands. An environmental profile of Kipahulu Valley provides a basis for understanding island diversity from tropical sea level to a sub-alpine summit. Dense vegetation makes the mid-elevation area one of the most impenetrable valleys in the State of Hawai'i. The annual rainfall gradient may vary from 2,000 $\mathrm{mm}$ near sea level to $4000 \mathrm{~mm}$ at $1000 \mathrm{~m}$, while maximum rainfall may exceed $7620 \mathrm{~mm}$. Descriptions of the valley made by research scientists in a 1967 expedition and elsewhere warrant the strict protected area management strategies regarding access and activities that have been in place for over three decades:

"That such an area still remains intact is ... to my knowledge unmatched anywhere else in (Hawai $\mathrm{i}$ ) and is a biotic reservoir of tremendous value" ... "These communities are like no other, and Kipahulu Valley in this sense offers an opportunity (for scientific research) not available elsewhere on the planet" (Warner, 1968: 89, 54 respectively).

The disruption by human activities of native ecosystems below $500 \mathrm{~m}$ and degradation by cattle grazing and feral pigs has left biotic communities in a state of constant change. The coastal zone first altered by Polynesian settlers became largely monoculture in the postcontact period. Hawaiians constructed agricultural terraces, waterways and building foundations that were cleared at random for sugar cane and pineapple plantations starting 


\section{J. Cusick}

in the $19^{\text {th }}$ century, and bulldozed later for commercial ranching. Alien tree species introduced in the modern period pose a serious threat to the native montane rainforest, and the disturbance of native vegetation and introduction of alien species, both intentionally and accidentally, have created conditions that favour aggressive alien species. The montane rainforest provides habitat for over 89 known species of ferns, 290 species of flowering plants, four endangered and 13 endemic or indigenous forest birds, and is a center of endemism in the State. The montane rainforest and sub-alpine grasslands are identified as the least disturbed in Hawai' $i$.

Portions of the valley are recognized as a National Park, Scientific Research Reserve, Wilderness Area, and International Biosphere Reserve (Table 1). The Haleakala National Park 2005-2008 Strategic Plan recognized the need for a monitoring program of "key vital sign parameters" in response to visitor impacts in order to improve the overall visitor experience (Haleakala National Park, 2005). The goal of the monitoring program is to increase appreciation of the character and value of native ecosystems and cultural resources by the approximately 1.5 million annual visitors and, therefore, minimize negative impacts by means of effective resource and visitor management.

Table 1: Chronology of Protected Area Designation of Kipahulu Valley.

\begin{tabular}{ll}
1916 & Haleakala Crater area included in Hawai‘i National Park \\
1951 & Upper Kipahulu Valley incorporated into Hawai'‘ National Park \\
1961 & Haleakala National Park established \\
1969 & Kipahulu District, Haleakala National Park established, Upper Kipahulu \\
& Valley designated Scientific Research Reserve \\
1976 & Kipahulu Historic District candidate as National Historic Place \\
1976 & Haleakala National Park Wilderness Area designated \\
1980 & Designation of Haleakala National Park IBR \\
\hline
\end{tabular}

\section{Tourist Destination}

Geographic isolation due to islandness, a rugged topography and unpredictable seas in East Maui delayed the cultural disruption of traditional practices experienced throughout the islands until the mid-1800s when commercial sugar production was unsuccessfully attempted in several East Maui locations. As a result of the small scale of operations and relatively brief period of plantation agriculture, compared to other areas in the Hawaiian Islands, East Maui remained rural with limited commercial and residential zoned parcels.

Large tracts of land in East Maui were put up for sale after the failure of commercial agriculture in the 1930s. The purchase of 5,700 hectares in the early 1940s established Hana Ranch and the Hotel Hana-Maui was built in 1946. This initial foray into tourism for East Maui put Hana on the route of adventurous and privacy-seeking travelers at the start of Hawai'i's post-war tourism boom. Tourism development in East Maui in the post- 
statehood period did not have as visible an impact as it did in Central and West Maui. Unlike Ka'anapali, Kapalua, Kihei, and Lahaina, where tourism has systematically transformed communities and landscapes over the past half century, East Maui is relatively isolated from most mass-tourism development. Nonetheless, tourist traffic in rental cars and tour vans through these communities is a daily reminder of the dominance of the tourist industry on the island.

Coastal cultural landscapes set among a backdrop of mountain topography were the primary driving forces behind the growth of tourism in East Maui and continue to be the image mythologized in travel literature beginning in the 1960s as representative of the "old Hawai 'i" that was quickly being lost on O'ahu. Hotel Hana-Maui was marketed to provide luxury accommodations in a remote and isolated setting "far from Waikiki" where wealthy travellers could relax in a tropical rural environment.

In the case of Maui, tourism's demands are acute as operators continually search for new venues to market and exploit. For some visitors to East Maui, "it's sheer heaven to enjoy one of Maui's most scenic journeys in an air-conditioned vehicle with panoramic windows" (Janes, 1997). However, that degree of comfort may not necessarily be an attraction for ecotourists; nor are East Maui's exclusive hotel and famous residents the major attractions.

According to the tourist brochure "101 Things to Do on Maui," images of lush tropical valleys and waterfalls attract visitors with perhaps a couple on horseback enjoying an expansive view. In reference to a photographic image of Kipahulu Valley, the brochure states that "with a little guidance and perhaps some luck you may stumble upon this breathtaking bluff on the ridge above Ohe"o Gulch" (Gardiner, 1999). Kipahulu District is noted as one of the "least visited" national parks in the country "yet perfect for the folks seeking a quiet, nature experience." The emphasis is on experiences with nature, but the connection to a cultural past is still alive in East Maui, as epitomized by its description as a cultural kipuka.

Tourism operators not only compete with each other but also with other operators based elsewhere. Ecotourism destinations also compete with other places that are in some respects more biologically diverse, Central America for example. The challenge for "lucrative ecotourism" is to integrate conservation and development while acting on the promises of increasing environmental education (Oliver, 1999). If no such connection is made then ecotourism will be the passing fad it is at times described as due to short-term financial objectives over long-term planning.

\section{Intersection of Resident, Research and Recreation Stakeholder Interests in East Maui}

The island of Maui has now become a major tourist destination, with nearly 2.5 million visitors who generate over US\$3 billion in visitor expenditures every year (DBEDT, 2006). The island became a major tourism destination through conversion of sugarcane and pineapple plantation landscapes and infrastructure to tourist destinations, resorts, and 


\section{J. Cusick}

infrastructure, including resort properties with golf courses and luxury second homes, construction of commercial retail space, redirection of water resources from agriculture to urban uses, and road improvements. Dramatic increases in resident and visitor populations, total number of hotel rooms, employment opportunities, state tax collections, and business receipts from the 1970s to the end of the century suggest that the development strategy was an economic success (Blackford, 2001). Sixty-three percent of the tourists to Maui in 2006 were repeat visitors who averaged 4.6 previous visits to the island (DEBDT, 2006).

Marketing Maui as a tourist destination was initiated at the time of statehood in 1959, and twenty years later the island appeared in a six-page essay in Time magazine dubbing Maui "America's Magic Isle" (Blackford, 2001). Considered a perennial favourite among many tourists, Maui is regularly voted by Conde Nast Traveler readers as the best island destination in the Pacific.

A recurring theme in resident interviews is sustainability. Tourism development is considered by some interest groups on Maui as part of the problem and not the solution, despite job creation and improved transportation infrastructure. Residents generally agree that roads serve the vital role of providing government services to rural communities, but as mobility increases as transportation infrastructure expands, there is also recognition that the government has the responsibility to minimize negative impacts through zoning and resource management strategies.

Kipahulu is not a major tourist destination of the level experienced in central and west Maui communities of Kihei, Paia, or Lahaina; and protected area status mandates protection of a high quality experience. East Maui is easily accessible yet relatively remote involving a more than two hour drive from the concentration of visitor accommodations on the island. The tourist experience on Maui, compressed in time and space, is largely dictated by transportation, in that a lack of public transportation options or safe bicycle lanes requires visitors to rely on rental cars with all the associated support, services, and pollution. Auto travel may be out of place on islands in general with limited infrastructure and a complete dependence on imported fossil fuel.

East Maui, and Kipahulu in particular, is an area where residents simultaneously resist assimilation and re-create cultural landscapes to educate visitors (including in-state residents) of the past and to provide a view of an emerging future associated with the renaissance of Native Hawaiian identity (Map 2). Resurrected in 1995, a group of residents and volunteers continue the work initiated by their elders who negotiated an agreement with Haleakala National Park to reclaim ancestral lands for the purpose of re-establishing agricultural fields that had lain dormant for over a century. The objective of the non-profit Kipahulu 'Ohana is to restore and nurture a cultural landscape toward the goal of establishing a viable working agricultural community. 


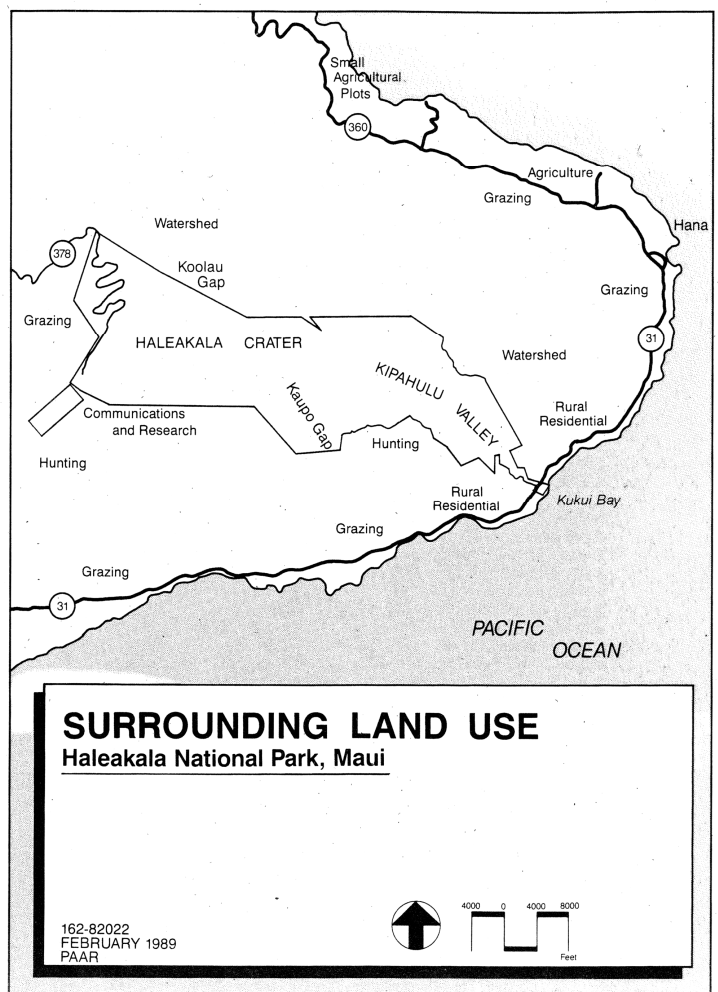

Kapahu Living Farm is situated within the boundaries of Kipahulu District, Haleakala National Park where more than a dozen $l o{ }^{\prime} i$ (irrigated agricultural field) grow kalo (taro). In adjacent gardens and forest understory, there are many of the principal crops brought to the Hawaiian Islands by Polynesian voyagers, including 'uala (sweet potato), 'ulu (breadfruit), mai'a (banana), ko (sugarcane), and the 'awa plant which is used in ceremonies and as a medicinal treatment. The addition of hale (buildings) serve as gathering sites for demonstrations and discussions for the educational purposes of residents, researchers and recreationists alike. The Kipahulu 'Ohana began as a project to create a "living history program to share with park visitors" (Monson, 2002: 1). It has become much more than a farm since its inception and is evidence of indigenous collaboration largely absent in U.S. National Parks (Burnham, 2000).

Map 2: Surrounding Land Use, Haleakala National Park, Maui.

Source: National Park Service (1998).

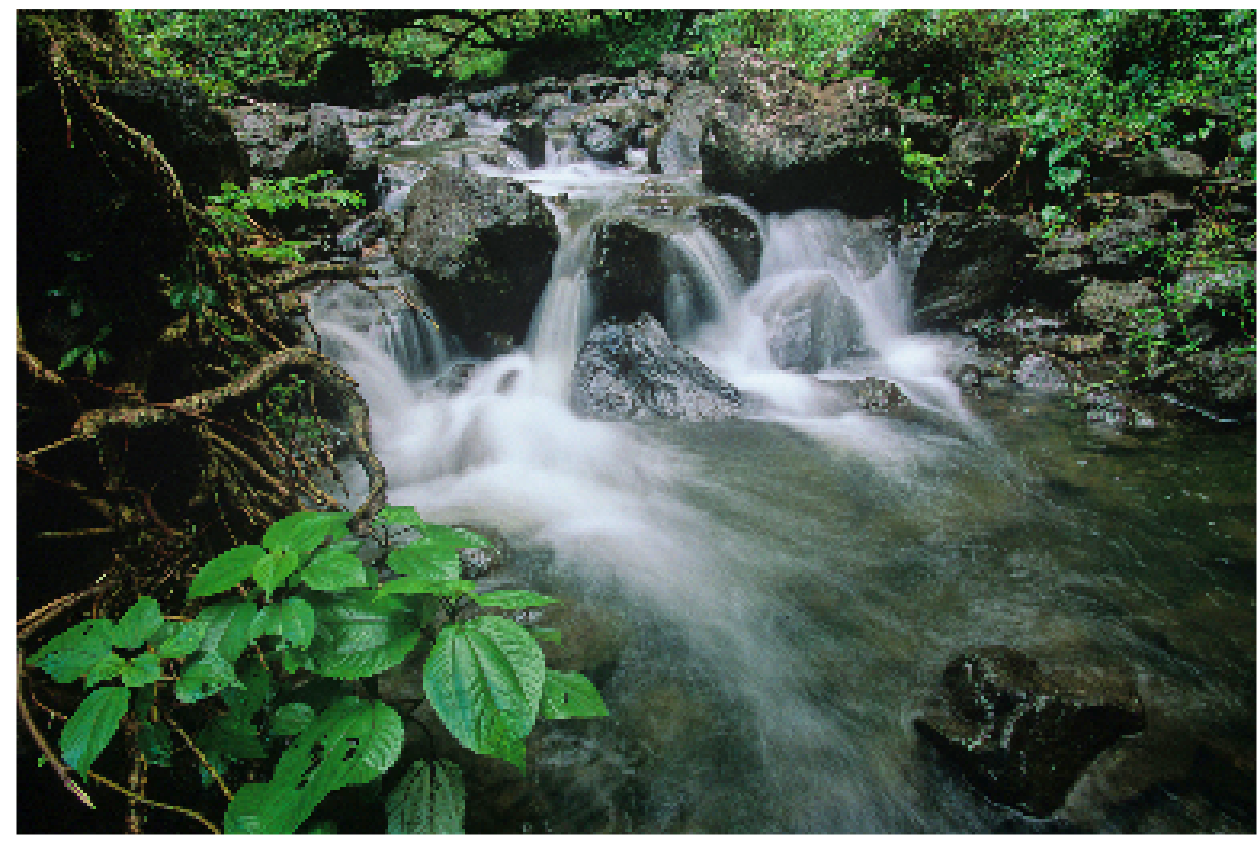

Photo 1: Kipahulu District, Haleakala National Park, Maui.

Source: Bob Butterfield: http://www.agpix.com/butterfield 


\section{J. Cusick}

Community assistance comes in many forms and with certain conditions. Current alliances have brought about and nurtured the perpetuation of culture and the conservation of biodiversity as stakeholders recognize the shared benefits of partnerships. Kipahulu 'Ohana is working in an area where jobs are scarce and land expensive, so volunteers contribute their labour to care for the farm and, in so doing, they (re)connect with the host culture, often, but not always, their own.

Shared labour among stakeholders is a component of the community-based economic development objectives inspired by ecotourism and sustainability initiatives. Projects foster unity among stakeholders, particularly residents who share the challenges associated with an unpredictable service economy. Partnerships enable residents to earn a living "in their own backyard" rather than making the minimum two-hour commute to centres of employment in central and West Maui (Monson, 2002). Despite periods of animosity and antagonism, the National Park status of Kipahulu District can be considered an asset that distinguishes East Maui from other cultural kipuka that lack protected area status (e.g. Photo 1). As a result, school children from Hana and other communities regularly visit the farm and experience what has been referred to as "living in the context of the past."

Improved relations may be attributed to expanded contacts among stakeholders. This is particularly important given the strained community relations that resulted from initial inclusion of Kipahulu Valley into National Park boundaries in 1969. Protected areas advocate Laurence Rockefeller proposed to contribute his coastal property to Haleakala National Park by challenging The Nature Conservancy to raise funds and purchase private lands in the valley in order to link the contiguous properties with the existing Crater District at the summit of Haleakala. The State of Hawai'i donated 1,200 ha of upper montane forest reserve, and Project Kipahulu as it became known, successfully expanded park boundaries from the summit of Haleakala to the ocean.

A consensus at the time among research stakeholders was that protected area designation for the valley was necessary and the appropriation process justified. In fact, after receiving National Park designation, Kipahulu Forest Reserve became a Scientific Research Reserve, and later a Wilderness Area and International Biosphere Reserve due to the concentration of biological diversity, including endemic species that were being added to the endangered species list or were at risk of extinction.

Meanwhile, the lower valley serves as a buffer zone and centre for visitor activities as promoted by recreation stakeholders. The National Park Service, having managed the summit area since 1916, is involved in partnerships with State agencies and private organizations, including the Kipahulu 'Ohana, The Hawai'i Natural History Association, The Nature Conservancy, The Friends of Haleakala National Park, and the East Maui Watershed Partnership. As a result of stakeholder cooperation, a network of protected areas in East Maui stretches uninterrupted across the biologically diverse windward and leeward upper montane forests above approximately $300 \mathrm{~m}$ elevation. 
One outcome is that residents have reconstituted the identity of Kipahulu as a Hawaiian place with benefits to various stakeholders. Protected area status perpetuates a perception of significance that dates back centuries, during which time generations of residents cared and fought for East Maui.

\section{Challenges in Establishing Community-Based Tourism}

Despite the identity makeover for much of the Hawaiian Islands to accommodate the tourism gold rush of the late $20^{\text {th }}$ century, East Maui retains a relatively independent identity. The identity of East Maui as a "last Hawaiian place" enables a distinction from the rest of Maui, let alone most places on the other islands. Although the claim is exaggerated, it permits a degree of resistance to forms of development that would undermine the image of a place that has perpetuated despite widespread disruption of natural and cultural environments (Farrell, 1992).

Resistance to mass tourism development in East Maui has taken several manifestations in the past decades. One community action successfully opposed construction of a countyapproved 18-hole golf course on Hana Ranch land. Successive owners concluded that a golf course was the way to compete with other tourist destinations for market share (Fujimoto, 1991). Hana residents thought otherwise and contested the owner's claim that no golf course would equal no jobs for residents.

Residents responded "Everything we have seen so far indicates [that the Hana Ranch owners] are not going to be able to make it economically viable" (Fujimoto, 1991). The South and West Maui coastlines were under a major transformation at the time with the development of condominiums, hotels, time-shares, luxury homes, and golf courses (Blackford, 2001). Residents were convinced that a golf course in central Hana would not have a competitive advantage due to physical isolation and difficult accessibility, merely having to recall East Maui's inability to compete with Central Maui during the plantationera for similar reasons.

Residents made the case that a golf course is not the landscape or activity tourists are looking for in planning an East Maui vacation. East Maui, along with other places with concentrations of environmental diversity, is the target of "hordes of nature-loving tourists" according to a Honolulu Advertiser front-page story (Conrow, 1997). In fact, state land managers worried that already overused resources "will be swamped" by the incoming waves of nature tourists. Those visitors who prefer a forest hike or encounter with marine ecosystems - such as snorkelling, scuba diving, and whale watching - may be less interested in a round of golf or sitting idly on a beach. Opposition to a golf course in East Maui was further based on concerns over water quality, the quality of rural lifestyles, and the scale and number of luxury homes to be built along fairways that would disrupt cultural landscapes and viewscapes envisioned by supporters that maintain East Maui's distinctive attraction to ecotourism. 


\section{J. Cusick}

Preserving the cultural landscape of East Maui is an underlying theme of resident resistance. "It's not only a community, it's a big family" (Gordon, 1997). That "family" is what elders want to impress on younger generations, as it is the spirit of the place that residents are concerned about losing for future generations. In the context of this vision, conservation of biological diversity, preservation of cultural sites, and perpetuation of traditions go hand-in-hand and will be the work of $21^{\text {st }}$ century residents of cultural kipuka in the Hawaiian Islands. "Understanding this provides a more sensitive and richer framework for future land use planning and government policies. Without such understanding, our actions may be blunt and clumsy, and our vision incomplete" (Atta, 1995).

A sustainability framework suggests a reappraisal of how to nurture, not alter, East Maui's identity. Stakeholders in East Maui are inclined to advocate for plans that are conducive to sustaining natural resources; those that feed and employ residents, are the source of knowledge and understanding for researchers, and are the attractions to those with the leisure and income to recreate in distant locations:

"The District not only represents a priceless resource in culture, history, agricultural richness, and human dignity; even more important, Hana is everyone's reigning symbol that the wild spirit of this land has not yet fallen under the orderliness of concrete and the tidiness of leaf blowers" (Maui News, 1997).

It is not an overstatement that East Maui provides a contrast to the rest of the islands. Many stakeholders consider East Maui an opportunity to plan with vision, "to get it right," and for all stakeholders to benefit:

"None of us wants to belong to the generation that lost Hana. If that's so, however, we have a lot of work to do, and now" (Maui News, 1997).

\section{Conclusion}

Cultural kipuka persist as centres of environmental diversity in the State of Hawai'i largely because plantation agriculture - both sugarcane and pineapple, in the case of East Maui became uneconomical by the late 1800 s and early 1900 s. Western commercial activities and Christian missionaries arrived later in these isolated island areas, protected by geographic obstacles, than in more accessible locales. This isolation, and lack of commercial viability, fostered the continuation in these areas of many traditional Hawaiian cultural and land use practices into the 21 st century. Consequently, these areas are also significant to research and recreation stakeholders who now have a vested interest in the conservation and/or preservation of cultural kipuka, albeit for reasons that place their interests in both cooperation and competition with residents.

Ecotourism is an underdeveloped niche market in Hawai' $i$; yet, it has significant potential and is well placed to provide an important alternative to resort-based tourism. While some agreement has been reached about the conceptual definition of ecotourism in the context of the Hawaiian Islands, further research is required to investigate the viability of ecotourism 
and analyze the private and public costs and benefits of this market, particularly within a Hawaiian cultural and archipelagic context.

Progress was made over the last two decades in support of alternatives to mass tourism. Given the Hawaiian Islands' environmental diversity and cultural heritage, ecotourism is expected to continue to be a topic of interest to stakeholders. A research agenda with a focus on broadening the understanding of the various stakeholders will contribute to future planning for, management of, and decision-making regarding the fragile, and threatened, ecosystems and associated rural lifestyles that are unique to the Hawaiian Islands.

The politics of protected areas involves accommodating conflict with policies that balance development and conservation. Equally important is adjustment to conditions of particular places and strategies of development that consider the impacts of increasing numbers of annual visitors on resident or research interests or activities. The promotion of ecotourism may facilitate the effectiveness of protected area management, but may not provide sufficient motivation for residents to embrace a conservation ideal imposed by external interests regardless of intentions.

Resident perceptions of sacred status are considered to be reaffirmed by internationally recognized protected area status. Residents welcome others to experience their places, but hope that representations not be limited to tourism promotions and/or scientific descriptions of natural and cultural resources. This situation is similar to other cultural kipuka in the Hawaiian Islands, where environmental quality and cultural integrity may be deciding factors in sustaining resident place, research field sites and tourist destinations.

Sustainable development, having emerged as part of an effort to ensure human survival in a time of global environmental change, allows Kipahulu Valley's protected area status to monitor ecological and human adaptations and the lessons learned that can inform other protected area managers and adjacent resident communities. In this capacity, the Hawaiian Islands' marine and terrestrial biodiversity and cultural heritage provide lessons for managing human activities toward a sustainable future.

\section{References}

Atta, G. (1995) 'Preserving a Cultural Landscape’, The Honolulu Advertiser, June 18, B1.

Beeton, S. (1998) Ecotourism: A Practical Guide for Rural Communities, Collingwood, Landlinks Press.

Bjork, D.P. (2000) 'Ecotourism from a Conceptual Perspective: An Extended Definition of a Unique Tourism Form', International Journal of Tourism Research, Vol. 2, No. 3, pp. 189-202.

Blackford, M. (2001) Fragile Paradise: The Impact of Tourism on Maui: 1959-2000, Lawrence KS, University Press of Kansas. 


\section{J. Cusick}

Blamey, R.K. (1997) 'Ecotourism: The Search for an Operational Definition', Journal of Sustainable Tourism, Vol. 2, No. 1, pp. 109-130.

Boo, E. (1990) Ecotourism: Potentials and Pitfalls, Washington DC, World Wildlife Fund.

Brause, D. (1992) 'The Challenge of Ecotourism: Balancing Resources, Indigenous People and Tourists', Transitions Abroad, November-December, pp. 29-31.

Buckley, R. (2004) 'Impacts Positive and Negative: Links between Ecotourism and Environment' in R. Buckley (ed.) Environmental Impacts of Ecotourism, Wallingford, CAB International, pp. 5-15.

Buckley, R. (ed.) (2004) Environmental Impacts of Ecotourism, Wallingford, CAB International.

Bulbeck, C. (2005) Facing the Wild: Ecotourism, Conservation and Animal Encounters. London, Earthscan Publications.

Burnham, P. (2000) Indian Country, God's Country: Native Americans and the National Parks, Washington DC, Island Press.

Carr, A.M. \& Higham, J.E.S. (2001) 'Ecotourism: A Research Bibliography', Dunedin, New Zealand, University of Otago.

Conrow, J. (1997) 'Ecotourism: Public Lands, Private Business', Honolulu Star-Bulletin, April 1, A1.

Cusick, J. (2007) 'Lessons from Kipahulu District, Haleakala National Park', Mountain Forum Bulletin, Vol. 7, No. 1, pp. 17-19.

Cusick, J., McClure, B. \& Cox, L. (in press) 'Representations of Ecotourism in the Hawaiian Islands: A Content Analysis of Local Media’, Journal of Ecotourism.

Diamantis, D. (2004) Ecotourism: Management and Assessment, London, Thomson.

Dondo, M. (1959) La Perouse in Maui, Wailuku HI, Maui Publishing Co.

Drumm, A. \& Wesche, R. (1999) Defending Our Rainforest: A Guide to CommunityBased Ecotourism in the Ecuadorian Amazon, Washington DC, Island Press.

Eagles, P., Nilsen, P., Kachi, N. \& Buse, S. (eds.) (1995) Ecotourism: An Annotated Bibliography for Planners and Managers, North Bennington VT, The Ecotourism Society.

Farrell, B. (1992) 'Tourism as an Element in Sustainable Development: Hana, Maui' in V. Smith \& W. Eadington (eds.) Tourism Alternatives Potentials and Problems in the Development of Tourism, Philadelphia PA, University of Pennsylvania Press, pp. 115-134. 
Fennell, D.A. (2001) 'A Content Analysis of Ecotourism Definitions', Current Issues in Tourism, Vol. 4, No. 5, pp. 403-421.

Fennell, D.A. \& Eagles, P.F.J. (1990) 'Ecotourism in Costa Rica: A Conceptual Framework'. Journal of Park and Recreation Administration, Vol. 8, No. 1, pp. 23-34.

Font, X. \& Tribe, J. (2001) 'Promoting green tourism: the future of environmental awards', International Journal of Tourism Research, Vol. 3, No. 1, pp. 9-21.

France, L. (ed.) (1997) The Earthscan Reader in Sustainable Tourism, London, ETC UK.

Fujimoto, L. (1991) 'Golf Course Talk driving Hana apart', The Honolulu Advertiser, November 21, A1, A8.

Gardiner, G. (1999) 101 Things to Do on Maui, Honolulu HI, EBMC.

Godde, P., Price, M. \& Zimmermann, F. (2000) Tourism and Development in Mountain Regions, New York, CAB International.

Gössling, S. \& Hall, C.M. (eds.) (2006) Tourism and Global Environmental Change: Ecological, Social, Economic and Political Interrelationships, London, Routledge.

Gordon, M. (1997) 'Hana embodies Spirit of Noel', The Honolulu Advertiser, December $15, \mathrm{~A} 1-2$.

Harvey, J., \& Hoare, A. (1995) 'Benefits to Local Communities from Ecotourism' in L. Haysmith \& J. Harvey (eds.) Nature Conservation and Ecotourism in Central America, Florida, Wildlife Conservation Society, pp. 52-64.

Hawai'i 2050 Sustainability Task Force (2008) Hawai $i 2050$ Sustainability Plan, Honolulu HI, State of Hawai'i.

Hawai'i Department of Business, Economic Development and Tourism (DBEDT) (2006) Planning for Sustainable Tourism: Summary Report, Honolulu HI, Hawai'i Department of Business, Economic Development, and Tourism.

Hawai'i Tourism Authority (2004) Ecotourism in Hawai 'i: White Paper, Honolulu HI, Hawai'i Tourism Authority.

Haysmith, L. (1995) Potential Negative Impacts from Ecotourism on the Environment' in L. Haysmith \& J. Harvey (eds.) Nature Conservation and Ecotourism in Central America, Florida, Wildlife Conservation Society, pp. 78-101. 


\section{J. Cusick}

Higham, J.E.S. \& Carr, A.M. (2003) 'Defining Ecotourism in New Zealand: Differentiating between the Defining Parameters within a National/Regional Context'. Journal of Ecotourism, Vol. 2, No. 1, pp. 36-51.

Hinch, T.D. (1998) 'Ecotourists and Indigenous Hosts: Diverging Views on their Relationship with Nature'. Current Issues in Tourism, Vol. 1, No. 1, pp. 120-124.

Honey, M. (1999) Ecotourism and Sustainable Development: Who Owns Paradise?, Washington DC, Island Press.

Horwich, R. Murray, D., Saqui, E., Lyon, J. \& Godfrey, B. (1993) 'Ecotourism and community development: a view from Belize' in K. Lindberg \& D.E. Hawkins (eds.) Ecotourism: Guide for Planners and Managers, North Bennington, The Ecotourism Society, pp. 152-165.

Howe, J., McMahon, E. \& Propst, L. (1997) Balancing Nature and Commerce in Gateway Communities, Washington DC, Island Press.

Janes, L. (1997) 'On the Bus to Hana as a Tourist for a Day', Maui News, 16 March, C1, C7.

Kirch, P. (1985) Feathered Gods and Fishhooks: An Introduction to Hawaiian Archaeology and Prehistory, Honolulu HI, University of Hawai'i Press.

Knight, R.L. \& Gutzwiller, K.J. (eds.) (1995) Wildlife and Recreationists: Coexistence Through Management and Research, Washington DC, Island Press.

Kornbacher, B. (1993) 'Archaeological Inventory of Ka'apahu Subdivision Remnant Lots 5, 6, and 7 and the Hana Highway Corridor, Kipahulu, Hana, Maui, Hawai'i', Honolulu HI, International Archaeological Research Institute.

Krauss, B. (1980) 'Ethnobotanical Resources in Kipahulu Valley below 2000 feet' in C. Smith (ed.) Resources Base Inventory of Kipahulu Valley below 2000 feet, Cooperative Park Studies Unit, Technical Report No. 43, Honolulu HI, University of Hawai‘i.

Kruger, O. (2004) 'The Role of Ecotourism in Conservation: Panacea or Pandora's Box?', Biodiversity and Conservation, Vol. 1, No. 22, pp. 1-25.

Larsen, L. \& Wearing, S. (1994) Assessing and Managing the Socio-Cultural Impacts of Ecotourism: Revisiting the Santa Elena Rainforest Project, Australia, Sydney University of Technology.

Lindberg, K. \& Hawkins, D. (eds.) (1993) Ecotourism: A Guide for Planners and Managers, North Benington VT, The Ecotourism Society.

Liu, J. (1994) Pacific Islands Ecotourism: A Public Policy and Planning Guide, Honolulu HI, Pacific Business Center Program, University of Hawai'i at Manoa. 
Lockwood, M., Worboys G. \& Kothari, A. (eds.) (2006) Managing Protected Areas: A Global Guide, London, Earthscan.

Lueras, L. (1983) On the Hana Coast: Being an Account of Adventures, Past and Present, in a Land where the Hand of Man seems to rest lightly, Honolulu HI, Emphasis International.

Mak, J. (2008) Developing a Dream Destination: Tourism and Tourism Policy Planning in Hawai ' $i$, Honolulu HI, University of Hawai'i Press.

Maui News (1997) 'Kipahulu 'Ohana', The Maui News, 1 March.

McCool, S.F. \& Moisey, R.N. (2001) Tourism, Recreation, and Sustainability: Linking Culture and the Environment, Wallingford, CAB International.

McGregor, D. (1995) 'Waipi'o Valley, a cultural kipuka in early $20^{\text {th }}$ Century Hawai'i'. The Journal of Pacific History, Vol. 30, No. 2, pp. 194-209.

Minerbi, L. (1991) Alternative Forms of Tourism in the Coastal Zone: Searching for Responsible Tourism in Hawai' $i$, Honolulu HI, University of Hawai'i, Department of Urban and Regional Planning.

Minerbi, L. (1994) A Framework for Alternative and Responsible Tourism: Eco-cultural Tourism, Honolulu HI, University of Hawai'i Department of Urban Planning.

Monson, V. (2002) 'Kipahulu 'Ohana helps bring Culture to Visitors', The Maui News, 21 July, pp. A1, A5.

National Park Service (1989) Statement for Management, Honolulu HI, Department of the Interior.

National Park Service (2005) Strategic Plan for Haleakala National Park, Fiscal Year 2005-2008, Honolulu HI, Department of the Interior.

Oliver, C. (1999) 'Walking to the Future', The Honolulu Advertiser, 21 November, pp. E1, E6.

Page, S.J. \& Dowling, R.K. (2002) Ecotourism, Harlow, Prentice Hall.

Peeters, P. (ed.) (2007) Tourism and Climate Change Mitigation. Methods, Greenhouse Gas Reductions and Policies. Breda, The Netherlands, NHTV.

Rohter, I. (1994) 'A Green Economy for Hawai'i. The Political Economy of Hawai'i'. Social Processes in Hawai 'i, Vol. 35, No. 1, pp. 124-144.

Scheyvens, R. (1999) 'Ecotourism and the Empowerment of Local Communities', Tourism Management, Vol. 20, No. 2, pp. 245-249. 


\section{J. Cusick}

Sheldon, P., Knox, J. \& Lowry, K. (2005) 'Sustainability in a Mature Mass-Tourism Destination: The Case of Hawai'i', Tourism International Review, Vol. 9, No. 11, pp. 47-59.

Smith, C., Williams, J. \& Asherman, K. (1985) 'Vegetation Map and Resource Management Recommendations for Kipahulu Valley (below 700 meters), Haleakala National Park', University of Hawai 'i Technical Report 53, Honolulu HI, University of Hawai'i, Cooperative Park Studies Unit.

Smith, V. \& Eadington, W. (eds.) (1992) Tourism Alternatives Potentials and Problems in the Development of Tourism, Philadelphia PA, University of Pennsylvania Press.

State of Hawai'i Department of Business, Economic Development and Tourism (2006) Planning for Sustainable Tourism: Summary Report, Honolulu HI, DBEDT.

Sterling, E. (1998) Sites of Maui, Honolulu HI, Bishop Museum Press.

Stevens, S. (ed.) (1997) Conservation Through Cultural Survival: Indigenous Peoples and Protected Areas, Washington DC, Island Press.

Stronza, A. \& Durham, W. (eds.) (2008) Ecotourism and Conservation in the Americas, Wallingford, CAB International.

Terborgh, J., van Schaik, C., Davenport, L. \& Rao, M. (eds.) (2002) Making Parks Work: Strategies for Preserving Tropical Nature, Washington DC, Island Press.

Warner, R. (ed.) (1968). Scientific Report of the Kipahulu Valley Expedition, Honolulu, HI, The Nature Conservancy.

Wearing, S. \& Neil, J. (1999) Ecotourism: Impacts, Potentials, and Possibilities, Oxford, Butterworth Heinemann.

Weaver, D. (1998) Ecotourism in the Less Developed World, Wallingford, CAB International.

Weaver, D. B. (2001) The Encyclopedia of Ecotourism, Wallingford, CAB International.

Whelan, T. (ed.) (1991) Nature Tourism: Managing for the Environment, Washington DC, Island Press.

Whitlock, W., Van Romer, K. \& Becker, R. (1991) Nature-Based Tourism: An Annotated Bibliography, Clemson, SC, Clemson University, Strom Thurmond Institute.

Zeppel, H. (2007) Indigenous Ecotourism: Sustainable Development and Management, Wallingford, CAB International. 